\title{
Renting and Sharing in Low-Income Informal Settlements: Lacunae in Research and Policy Challenges
}

\author{
Aabiya N. Baqai', Peter M. Ward ${ }^{2,3,4^{*}}$ \\ ${ }^{1}$ Community and Regional Planning at the School of Architecture, University of Texas at Austin, Austin, TX, USA \\ ${ }^{2}$ C.B. Smith Sr. Centennial \#1 Chair in US-Mexico Relations, University of Texas at Austin, Austin, TX, USA \\ ${ }^{3}$ Dept. of Sociology, College of Liberal Arts, University of Texas at Austin, Austin, TX, USA \\ ${ }^{4}$ L.B.J. School of Public Affairs, University of Texas at Austin, Austin, TX, USA \\ Email: aabiya.baqai@utexas.edu, *peter.ward@austin.utexas.edu
}

How to cite this paper: Baqai, A. N., \& Ward, P. M. (2020). Renting and Sharing in Low-Income Informal Settlements: Lacunae in Research and Policy Challenges. Current Urban Studies, 8, 456-483. https://doi.org/10.4236/cus.2020.83026

Received: August 13, 2020

Accepted: September 19, 2020

Published: September 22, 2020

Copyright $\odot 2020$ by author(s) and Scientific Research Publishing Inc. This work is licensed under the Creative Commons Attribution International License (CC BY 4.0).

http://creativecommons.org/licenses/by/4.0/

(c) (i) Open Access

\begin{abstract}
This paper describes the nature of low-income housing markets for renting and sharing in Latin America and the Caribbean. It reviews the importance of non-owner housing markets associated with early urbanization from the late nineteenth century to the mid-1940s when rental tenements of different types-often slums-predominated as migrant and worker housing. The rapid rise of informal settlements and self-building from the 1950s onwards inverted the tenurial status of low-income housing markets: "ownership" eclipsed renting, and whether informal or formal, became the primary mode of state supported housing production. However, as informal access to land slowed in the 1980s and 1990s, so renting and sharing began to emerge as subsidiary and increasingly important housing market alternatives, such that many cities are now showing a relative and significant decline in home ownership levels. Much of this rise in renting and sharing has occurred as a result of densification in the older, now consolidated, barrios that formed in the 1970s-90s. Despite this turnaround in low-income housing production and opportunities, public policy for non-ownership remains almost non-existent. Drawing upon detailed case studies, this article reviews the contemporary nature and dynamics of rental and shared housing across the region, and offers a series of policy approaches and instruments to promote both the supply and demand for non-ownership housing, primarily targeting the poor in the coming two decades.
\end{abstract}

\section{Keywords}

Informal Housing, Renting, Shared Accommodation, Latin America, Public Policy, Densification, Self-Help 


\section{Introduction: What Are the Challenges?}

Most developing country housing analysts will be very familiar with the widespread policy advocacy and implementation to improve conditions for informal self-building and homeownership going back to research in the late 1960s and 1970s, and the first UN-Habitat Conference held in Vancouver in 1976 (Turner, 1968; Gilbert \& Ward, 1982; Reyes et al., 2020). However, researchers and policymakers appear to know far less about other informal non-owner housing tenures such as renting and sharing which, for many households, form an integral and rising part of the Latin American and Caribbean housing market. ${ }^{1}$ This "fading-to-back" of the relative importance of rental and shared housing is in sharp contrast to the overwhelming research and policy focus upon self-built informal (spontaneous and "irregular" settlements) that were spawned by city-ward migration, urbanization and industrialization from the 1950s and 1960s onwards.

While most countries in the past two to three decades have since seen a marked slow-down in new irregular settlement formation, many of these earlier (older) settlements and dwellings from the 1960s-late1980s remain, and are no longer located in the urban periphery which has expended further outwards. Instead they form a first "ring" of primarily low-income self-built suburbs that are physically integrated into the city with good access to public transport, have basic services and infrastructure, and have brick and concrete dwelling structures comprising one, two, or three stories, brick-built and substantially "consolidated". From the late 1970s onwards, these originally low-density dwellings have often become the focus of public policies of "upgrading" and "regularization" (infrastructure and titling) and have offered a route to home ownership for the pioneer settlers-many of whom remain in those same lots today, albeit now elderly in their 60s or older-and for whom, de facto, a "home is forever", as Gilbert (1999) underscored. ${ }^{2}$ While it was not uncommon to find some rental rooms in those newly formed settlements, densities were low, ownership predominated (albeit de facto and without formal title), and non-ownership (renting) was rare -invariably below $10 \%$. Over time, however, densities rose as a result of family and household expansion, and as some informal settlers turned to petty landlordism and turned over dwellings or lots to low-income rentals.

From the 1990s onwards, many of these consolidated settlements and neighborhoods were subject to urban densification practices and policies under neoliberalism (Gilbert, 2016), although, as we shall observe below, these policies rarely, if ever, directly fostered renting and sharing. As a consequence, a high proportion of today's rental and non-ownership market lies precisely in these older

${ }^{1}$ See Scheba and Turok (2020) for descriptions of the dynamics of backyard rentals in South Africa, and the failure of government to respond appropriately.

${ }^{2}$ See also Ward (2012). "A patrimony for the children": Low-income homeownership and housing (im)mobility in Latin American cities. Annals of the Association of American Geographers, 102(6), 1489-1510. 
(now) consolidated areas of the city (Ward et al., 2015), and calls for formal rental policies have begun to appear in international agencies such as UN-Habitat and the IDB (Gilbert, 2003; Blanco et al., 2014).

In this paper we analyze the nature and dynamics of the non-ownership market, specifically among those who rent and share accommodation, and we have three overarching goals: first, to visualize and better understand the patterns of renting and sharing. Second, and as an offshoot of that analysis, we speculate about why scholarly interest in non-ownership appears to have been a "back burner" issue (relative to self-building for ownership); and why, in contrast with most developed and some developing nations, has policy making for non-owners in Latin America and the Caribbean struggled to get traction both among regional governments, as well as among in multi-lateral and non-governmental organizations? Understanding this lack of traction will help to address our third goal, which is to flesh-out a number of policy directions and considerations for sharing and renting through the middle of the twenty-first century. By then, if not before, we anticipate that the proportion of non-ownership to owners is expected to have flipped back to pre-World War II levels, when renting predominated in most countries.

\section{The Status Quo Ante: The Rise and Fall of Renting}

Renting Traditions Under Industrialization and Early $20^{\text {th }}$ Century Urbanization

Indeed, we sometimes forget how historically rental housing was widespread and important among low-income populations and migrants in Latin America, just as it was in Europe and the United States. The Industrial Revolution, migration, and urbanization changed the housing market in inner parts of capitalist cities like Paris, London, Manchester, New York and Chicago (Mayne, 2017; Wyke, Robson, \& Dodge, 2018). The shift from rural agricultural to industrial labor that accompanied urbanization in the $19^{\text {th }}$ century induced many of these changes. In order to cater to the demand for housing among the growing working classes, private landlords and sometimes the companies themselves, produced rental housing, many of which were slum tenements that offered cramped and squalid living conditions in which workers or worker households lived or shared space in a single room. Invariably the tenements lacked adequate sanitation and sewerage systems, and such limited services that existed, were shared.

So detrimental were the impacts of these conditions on the wellbeing of workers, that by the late $19^{\text {th }}$ Century and early $20^{\text {th }}$ Century policymakers were focused on legislation to improve sanitation and tenement living conditions (Fogeslong, 1986), and in places like the north of England where the industrial revolution was apace, developers and companies built rental row-housing for workers. While better than the tenements, these were also poorly ("jerry") built, and lacked adequate infrastructure, and along with tenements, later became the focus of slum urban regeneration and housing redevelopment programs. In the United States and elsewhere, subsidized public housing schemes were introduced as a 
means to clear up the tenements and provide affordable rental housing options to low-income communities. The Great Depression and the New Deal also brought about an increase in the subsidized housing market.

During and after WWII, the federal government continued its efforts in urban regeneration and in the support for working class rentals through policies of rent controls, and through government-led subsidies. However, for the most part, these schemes could not meet the demand due to poor regulation and maintenance, and housing production costs outpaced rental revenues. Instead, the shift to policies supporting homeownership through mortgage financing became the new norm, ultimately becoming associated with the "American Dream" (Federal Works Agency, 1941; Hoffman, 2000).

In Europe, the goal of the postwar period was to start afresh and revitalize war-torn towns through centralized planning that was a mixture of "technocratic, bureaucratic modernism" (Diefendorf, 1989: p. 132). Rental housing provision was mostly led by the public sector and were considered social or cooperative housing (Housing Europe (n.d.), https://www.housingeurope.eu/). In contrast to the US, national governments in Europe played a much more forceful and expanded role in the planning and housing development processes, which included as a priority, rental housing for low-income groups (Fainstein, 2020). In the UK, the development focused both on urban renewal programs (often to high- or low-rise rental council housing estates).

In Latin America, early urbanization occurred in the Southern Cone countries of Argentina, Uruguay, Chile and parts of Brazil such that by the end of the 19th Century renting had become the primary form of tenancy for the working class. The upper-class elite populations were the only ones owning property during this era, and they were beginning to vacate their inner-city mansions in favor of a move to the healthier suburbs, liberated by the rise of trams and rail networks (Scobie, 1974). Urbanization and industrialization came somewhat later to other Latin American countries, Mexico, and to the Caribbean, and accelerated at a different pace across the region especially from the late 1940s onwards into the 1950s and 1960s. The combination of rapid urbanization and the centrifugal movement of the elites vacating the city center in favor of the suburbs led to an influx of migrants into those vacated properties which were converted into tenements (Ward, 1998). In Mexico, so called vecindades were created from those mansions whose structures were subdivided into small single rental rooms around a patio area, with toilets and lavaderas (clothes and other washing areas) shared by dozens of families (Photo 1(a) \& Photo 1(b)). Alongside the classic vecindades such was the demand that it was profitable to build multiple occupancy tenements in the city center-at least up until the 1940s when rent controls made it less viable (Photo 1(c); Gilbert \& Varley, 2002).

Other cities saw similar conversions and rental construction in the city core: in Ecuador, conventillos were large urban homes abandoned by the wealthy as industrial growth attracted the working classes into the city center (Glasser, 1988); 


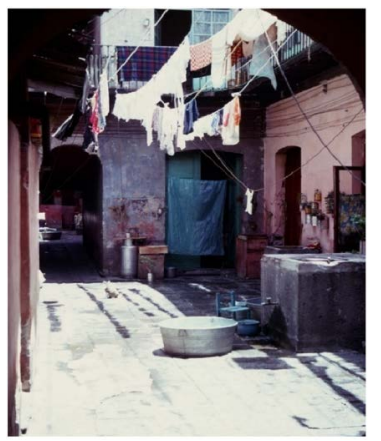

(a)

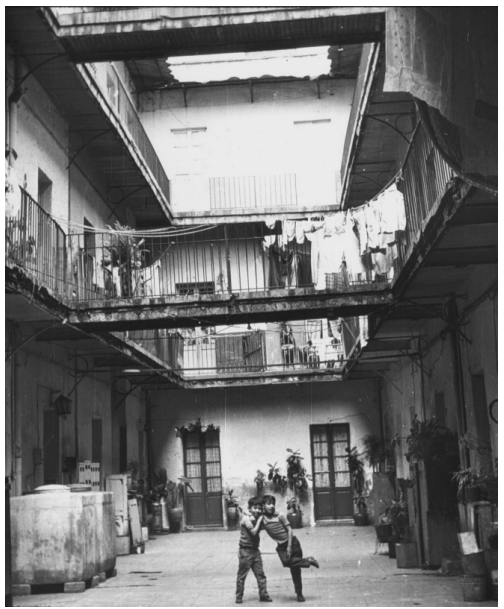

(c)

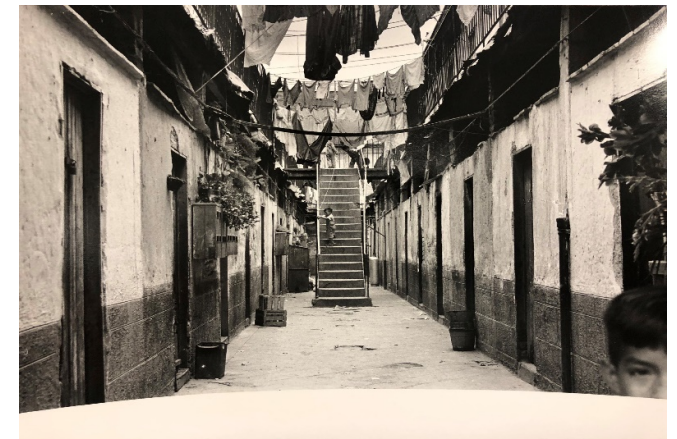

(b)

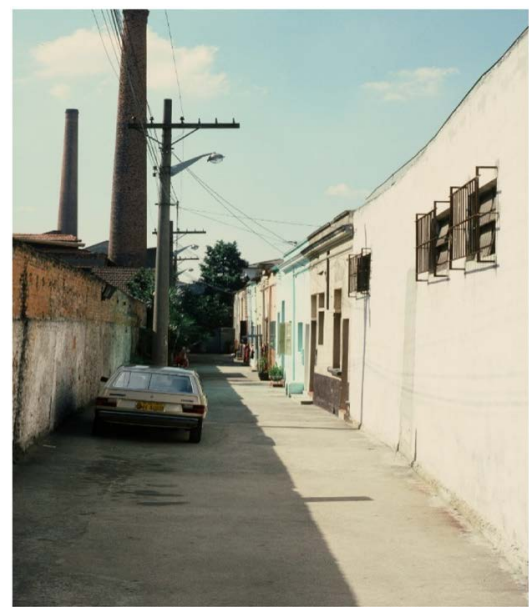

(d)

Photo 1. Early twentieth century images of different types of tenement housing. (Top left: (a): Traditional Vecindad(Converted18th Century Mansion) in City Center, Mexico City. Note multiple patios; two stories with single rooms off the patio at each level, and water fountain/cistern [author's photo]; Top right (b): "La Casa Grande” vecindad, [Oscar Lewis archive: University of Illinois Archives: Oscar and Ruth Papers 1944-1976, courtesy of Dr. Ricardo Ainslie]; Bottom left (c): Purpose-built 1920s vecindad Mexico City, [author's photo]; Bottom right, (d): Early $20^{\text {th }}$ century, Villa Operaria, (Factory [left] and workers' housing [on right]), Bras, São Paulo [author's photo]).

and Chile had its conventillos which also accommodated the growing working classes in the city center. In Brazil, industrialization at the turn of the $20^{\text {th }}$ Century attracted working class populations into tenements (cortiços), or into company-built row-house bungalows alongside the factory called the villas operarias, often with a school and company shops (Photo 1(d); López et al., (2010)).

In Jamaica, the history of slavery, colonialism and sugar plantations initially meant that the population was largely rural, but from the mid- $20^{\text {th }}$ Century the emergence of new economic opportunities in cities such as Kingston, saw a rising population moving into the city center. To meet the demand, the government built tenement yard housing which was often sub-let further to other low-income dwellers, creating high density tenement and shack-yards. Many of these tenements, whether originally built by government or by the private sector, eventually became entangled in the informal typical shanty towns of Kingston 
(Clarke, 1983). Similar "backyard" shacks and "micro flats" (tenements) are observed today in South Africa (Scheba \& Turok, 2020).

The Decline of Renting and the Rise of (Informal) Ownership

The point to underscore here is that up until the 1940s, worker and low-income housing in cities in Latin America was almost entirely rental, and although varied in nature, it was typically low-quality, high-density, and lacking in adequate services and privacy (Photo 1). Poor living conditions and a rise in rents led to various protests throughout the region which governments sought to damp-down by introducing rent controls and by imposing housing quality regulations (Blanco et al., 2014). In the 1930s, some governments also established mortgage lending systems and financial institutions for homeownership for those who could afford to buy into such schemes. Later, in the 1960s, promoted by concerns of Cuba-style copycat uprisings and revolution, the Alliance-for-Progress created a institutions and policies to promote "social interest" housing, which while ostensibly for the urban poor, was steered largely towards the lower-middle classes and more powerful worker constituencies (military, railway workers, government bureaucrats, etc.).

However, rapid urbanization from the 1950s onwards meant that by the 1960 s and 1970s, central tenement housing and shack yards could no longer contain urban growth and in-migration (Gilbert \& Ward, 1982). Rent controls had made new tenement development (and maintenance) unprofitable, and many landlords abandoned their properties, leading to a decline in inner city rentals. Inner-city residents, many of whom were migrants, after several years living in tenements, looked for cheap land purchase or squatting opportunities for ownership and self-building in the periphery (Turner 1968; Gilbert \& Ward, 1982; Correa, 2015). So began the demographic shift to the urban periphery, and ultimately to the absolute decline of population in the inner-city core.

Governments, unable to provide sufficient housing for this rapidly rising worker population, took a laissez faire attitude towards the creation of informal settlement production (squatters, illegal land sales, developer subdivisions without services, etc.). The little public housing that was offered focused almost entirely upon ownership, or occasionally upon programs of urban clearance and resettlement. Although rental households continued to make up most the housing sector until the 1950s, the subsequent rapid expansion of informal settlement and self-building meant that within two decades, ownership had become the predominant form of tenancy (even though households did not have formal titles of ownership [Gilbert \& Ward, 1985]). Census data reveal that the relative proportion of renters to owners had flipped around by the 1960s and 1970s, although not all censuses were comfortable recording informal de facto land holding as "owners" and declared them "others". But the extent to which one could disaggregate renters from owners and others clearly, it was apparent that owners were now in the majority, as Table 1 indicates for a range of Latin American cities (see columns 1970s \& 1990s). 
Table 1. The rise of ownership since the 1950s, for selected cities of Latin America and the Caribbean.

\begin{tabular}{cccccc}
\hline Ownership Rates in Selected Cities & 1950 s & $1970 s$ & $1990 s$ & $2000 s$ & $2010 s$ \\
\hline C. de México & 25 & 43 & 70 & $\mathbf{7 4}$ & $\mathbf{7 0}$ \\
Guadalajara & 29 & 43 & 68 & $\mathbf{6 8}$ & $\mathbf{6 4}$ \\
Bogotá & 43 & 42 & 54 & $\mathbf{4 6}$ & $\mathbf{4 2}$ \\
Medellín & 51 & 57 & 65 & $\mathbf{5 4}$ & $\mathbf{4 8}$ \\
Cali & 53 & 58 & 68 & $\mathbf{5 1}$ & $\mathbf{4 0}$ \\
Santiago & 26 & 57 & 71 & $\mathbf{7 3}$ & $\mathbf{6 3}$ \\
Rio de Janeiro & 38 & 54 & 63 & $\mathbf{7 0}$ & $\mathbf{7 4}$ \\
São Paulo & 41 & 62 & 71 & $\mathbf{7 5}$ & $\mathbf{7 8}$ \\
Buenos Aires & 27 & 61 & 62 & $\mathbf{6 7}$ & $\mathbf{5 7}$ \\
Kingston & NA & NA & 44 & $\mathbf{4 5}$ & $\mathbf{4 6}$ \\
\hline
\end{tabular}

Source: Blanco, 2013: p. 19.

Within these newly-established informal settlements of the 1970s \& ' 80 s, field surveys offered some evidence for modest renting to migrants who were unable to find accommodation in the city center now that renting opportunities were in decline (Gilbert \& Ward, 1982). These usually comprised newly constructed smaller vecindades housing five to ten (rarely more) families (see Photo 2(a)) with shared services at the end of the patio. In Bogotás "pirate" subdivisions self-builders often let out a room-even if it was a shack-in an effort to help cover the higher relative costs of informal lot purchase in that city (Gilbert 1983; Ward, 2012).

From the 1990s onwards, the emergence of more effective planning and land development controls have become more widespread, leading to a decline in peripheral land available for capture, which has also led to lower rates of new informal settlement creation. The earlier self-constructed informal settlements now form some of the most dense and consolidated areas in major cities. Recent studies show between $25 \%$ to $60 \%$ of the population in Latin America's main cities live in informal housing (Blanco et al., 2014). Both newer settlements and older consolidated settlements have become important spaces for non-ownership housing options, such as renting and sharing (Photo 2(b)) (Gilbert, 2016).

Recent Changes in Intra-Urban Mobility Trajectories and the Renewed Rise of Non-Ownership

While there is variation across the region it appears that after roughly 50 years of state policies explicitly or implicitly encouraging home ownership, renting and sharing are on the rise with the proportion of owners in metropolitan areas stabilizing or in modest decline, and Table 1 shows that ownership has declined by several percentage points since 2000. Given the relative population size of these metropolitan areas, this shift is indicative of a large absolute population that are seeking out rental housing especially in the older consolidated self-built settle- 
ments. Abramo (2019) shows that in Rio de Janeiro the share of the informal rental market in consolidated settlements in 2002 was 15\%, while in 2006 this had increased to $29 \%$. Moreover, because of rising demand, rental costs were also increasing such that $80 \%$ of the demand was for single rooms in the more central (better located) consolidated neighborhoods. In the case of São Paulo, census data show that while the overall proportion of renting barely increased between $2000-2010$ (22\% to $23 \%$ ), in peripheral settlements it almost doubled (from $15 \%$ to $26 \%$ ), and in one recent study of a large favela that surge has continued through 2017, with certain sections of the neighborhood rising to over 50\% rental occupancy in newly created cortiços (Photo 3), and in in-home subdivisions (Stiphany, 2019; Stiphany, Ward, \& Palazzi, 2020).

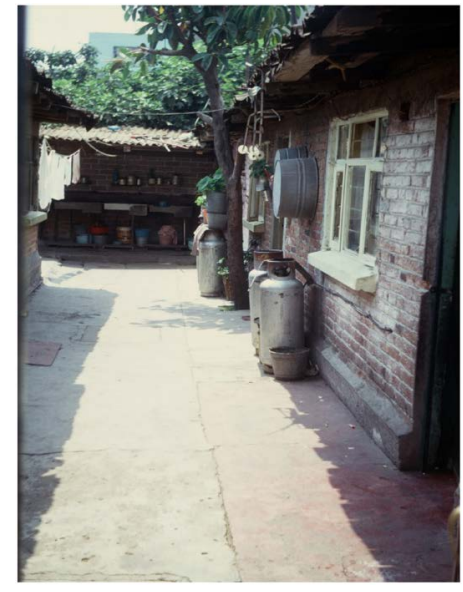

(a)

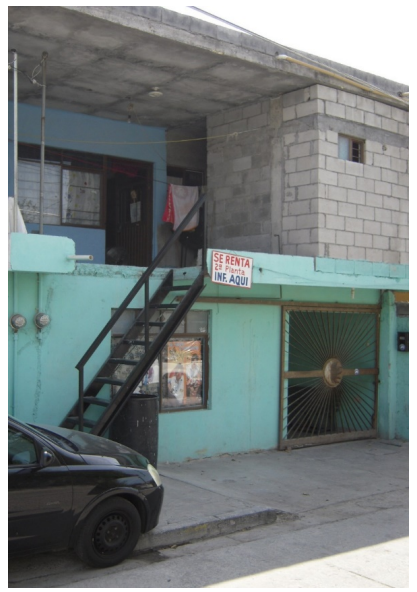

(b)

Photo 2. Contemporary renting in consolidated informal settlements. Left, (a): "New" vecindad-single rooms with gas tanks off a patio with services at the end (Mexico City); Right (b): Second floor rental, consolidated informal settlement in Monterrey, Mexico. [Author's photos].

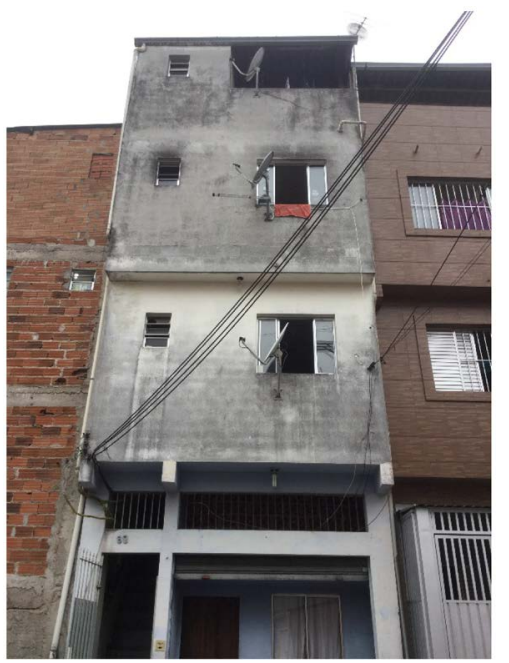

Photo 3. Cortiço tenement/micro-apartments in a consolidated favela, East Side São Paulo. [Photo courtesy of Dr. Kristine Stiphany]. 


\section{The Nature \& Status of Renting and Sharing-As We Know It Today}

In this paper we draw upon recent studies undertaken by the Inter-American Development Bank and by a small number of scholars who have analyzed non-ownership. ${ }^{3}$ Given the relative dearth of research materials on contemporary renting and sharing in Latin America and the Caribbean we also undertook five country-wide case studies on renting and sharing in order to build a more comprehensive comparative data and information base that might inform our enquiry into policy development for non-ownership (Antequera et al., 2020). The countries were: Brazil, Chile, Ecuador, Jamaica, and Mexico. ${ }^{4}$ This paper draws upon insights from those case studies in order to address our two primary goals: first to describe and characterize the nature of contemporary non-ownership patterns; and second, to focus upon scenarios and priorities for policy development over the next two decades.

The ongoing demand by would-be tenants motivates owners to become landlords, but generally in Latin America, landlords operate on a small scale and individually (Gilbert, 2012a). They are both male and female (especially in the informal sector), and are considerably older than their tenants-not surprisingly as some petty landlords are also part of the earlier generation of self-builder homeowners. Their business practices vary: some live onsite (in Bogotá for example), while others are "absentee" landlords living off-site (as in Mexico generally [Ward, 2012]). Some are more aggressive in promoting their landlordism roles. Generally, they prefer informal arrangements with tenants to avoid potential legal disputes and to maximize their flexibility to evict if necessary (Gilbert \& Varley, 2002). Because profit margins are small, they undertake limited maintenance and improvements on the property which, especially in older inner-city tenements, is often inherited and run by elderly widows (Gilbert, 2003). Sometimes, landlords only rent their property because they are unable to sell, and thus it is an alternative to abandonment.

Another form of tenure, that of sharing, is somewhat "messier" (less clear-cut) than renting. It usually occurs within family units, on a very informal basis. As Varley (1993: p. 13) states:

"'Sharing' occurs when two or more households occupy the same plot of land; one household owns the plot, allowing the other(s) to live there rent-free. Sharing mostly involves the adult sons or daughters of the plot owners, and may be regarded as a variation on the extended household

${ }^{3}$ While extensive research on renting exists in both developed and developing regions, the number of scholars who study renting can be counted almost literally on one hand, with Alan Gilbert being the only one who has done so systematically since the 1980s, and remains the single-most important authority on renting in Latin America and in comparative perspective.

${ }^{4}$ For the full report and case studies, see: Felipe Antequera, Aabiya Baqai, Grace Einkauf, Jorge Losoya, Katherine Murdoch with Peter M. Ward, 2020, Low-income Renting and Sharing in Latin American and Caribbean Cities: Towards a policy Agenda. DOI: https://doi.org/10.13140/RG.2.2.10751.23205. 
structure."

Often, it is tied to the immobility of informal settlement owners who allow kin, and especially close kin such as adult children, to occupy rooms in the dwelling or on the lot where they sometimes build their own separate dwelling. There is little guidance in the literature about policies to target sharers, but this form of housing is an important and expanding part of Latin American housing markets (Ward, Jiménez, \& Di Virgilio, 2015). Given that sharers are closely related to the owners (often adult children and their family), they are likely to eventually have a part share of the ownership rights to their parents' residence once the latter pass away (Grajeda, 2015; Grajeda \& Ward, 2012). Thus, while renters rarely have a track to become owners of their rental property; sharers do see it as a possible long-term route to ownership via inheritance.

The characteristics and expectations of landlords, renters, and sharers are important in formulating potential policies. As one can observe in Table 2, renters are likely to be individuals or young couples, be substantially younger than owners, and they are likely to stay in the same rental unit for a relatively short time (1 - 3 years is commonplace). Various factors shape their propensity to move around: conflicts with landlords; quarrels with neighbors; space needs; proximity to employment; or just looking for a better deal. Conditions are often crowded, heavily dilapidated, with shared services (w.c., shower, washing boards) - a déjà $v u$ of the slums of yesteryear. For the majority, renting is no longer a platform to later ownership - as it had been for the older generation of pioneer squatters and self-builders. In the formal market and in informal apartments, better-off renters generally enjoy higher quality accommodations and access to services.

Sharers also tend to be young adults, and they are usually the children or extended family members of owners. Their youth makes them more likely to be considerably better educated than their parents (since they were raised in the city), but contrary to the tendency among renters, sharers are less mobile, and although they may come and go and become renters nearby, those that remain on the lot (or return to it), are likely to stay longer than the short-term observed for renters, and in some cases have expectations to permanently remain on the lot-eventually inheriting from their parents.

The types and location of rental housing are also key variables in the discussion of rental and sharing policy. Units in the urban core (central city) are often older and comprise part of the formal market, with better access to services. Older self-help settlements now forming part of the intermediate ring, close-in to the urban core, have good access to infrastructure and transportation. At the periphery, self-built units have less access and are often made of lower quality materials. Table 2 and Table 3 summarize some of the various dimensions and attributes of tenants and their dwellings. 
Table 2. Tenant and sharer household characteristics.

\begin{tabular}{|c|c|c|c|}
\hline Tenant characteristics & Renters & Sharers & References \& Sources \\
\hline Age & Young (20s - $30 \mathrm{~s}$ ) & Young & $\begin{array}{l}\text { Gilbert, 1991; Ward, 1998; } \\
\text { Clarke,2006; Blanco et al., 2014; } \\
\text { Wardet al., 2015; Gilbert \& Varley, } \\
\text { 2002; Jiménez \& Camargo, } 2015\end{array}$ \\
\hline Household type & Couples or singles & $\begin{array}{l}\text { Couples with children or singles } \\
\text { (generally related to owners) }\end{array}$ & $\begin{array}{l}\text { Lewis, 1966; Hanson, 1975; } \\
\text { Gilbert, 1991; Kowarick, 1994; } \\
\text { Avilés et al., 2015; Ward et al., 2015; } \\
\text { Donoso-Gómez, 2018; } \\
\text { Howard, 2019; Stiphany, 2019; } \\
\text { Gilbert \& Varley, } 2002\end{array}$ \\
\hline Average tenure & $1-3$ years & $\begin{array}{l}\text { Sharers are often siblings (on or off site) } \\
\text { have varying aspirations to inherit, } \\
\text { acquire their own home, become renters } \\
\text { when they marry/set up home, etc. } \\
\text { Often unwilling to move to periphery } \\
\text { and self-build (as parents did). }\end{array}$ & $\begin{array}{l}\text { Gilbert, 1991; Ward et al., 2015; } \\
\text { Gilbert \& Varley, 2002; } \\
\text { Jiménez \& Camargo, 2015; } \\
\text { Blanco et al., } 2014\end{array}$ \\
\hline Income level & $\begin{array}{l}\text { Formal renters: moderate } \\
\text { Informal renters: low } \\
\text { Worse off economically } \\
\text { than "owners"/consolidators. } \\
\text { Informal renters often have poor } \\
\text { employment prospects, informal } \\
\text { economy, low wages. Those with } \\
\text { secure incomes and better off } \\
\text { will rent small apartments } \\
\text { with contracts (formal sector), etc. }\end{array}$ & $\begin{array}{l}\text { Varies; but much better educated } \\
\text { than parents. } \\
\text { Poor long-term prospects of } \\
\text { socio-economic mobility. }\end{array}$ & $\begin{array}{l}\text { Gilbert \& Varley, 2002; } \\
\text { Edwards, 1982; } \\
\text { Blanco et al., } 2014\end{array}$ \\
\hline Legal protection & $\begin{array}{l}\text { Relatively low, many } \\
\text { without contracts }\end{array}$ & None & $\begin{array}{l}\text { Eyre, 1972; Hanson, 1975; } \\
\text { Gilbert \& Varley, 2002; } \\
\text { Blanco et al., } 2014\end{array}$ \\
\hline $\begin{array}{l}\text { How they hear } \\
\text { about units }\end{array}$ & $\begin{array}{l}\text { Word of mouth or external } \\
\text { advertising ("se renta") }\end{array}$ & $\begin{array}{l}\text { Very barrio related (lived there all their } \\
\text { lives); especially daughters }\end{array}$ & $\begin{array}{l}\text { Gilbert \& Varley, 2002; } \\
\text { Jiménez \& Camargo, 2015; } \\
\text { Ward et al., } 2015\end{array}$ \\
\hline Maintenance of units? & $\begin{array}{l}\text { Rarely engage in self building or } \\
\text { serious in-house improvements }\end{array}$ & $\begin{array}{l}\text { Non-rent paying but shared } \\
\text { contributions for lot services, etc. } \\
\text { — contributions to parents }\end{array}$ & $\begin{array}{l}\text { Eyre, 1972; Hanson, 1975; } \\
\text { Stiphany, 2019; Gilbert \& Varley, } \\
\text { 2002; Jiménez \& Camargo, } 2015\end{array}$ \\
\hline Previous home & $\begin{array}{l}\text { Urban migrants in past; } 2^{\text {nd }} \& 3^{\text {rd }} \\
\text { generation city dwellers born today }\end{array}$ & $\begin{array}{l}\text { Kinsmen of owners: past would be } \\
\text { follow-on migrants; today usually } \\
\text { 2nd generation adult children }\end{array}$ & Gilbert, 1999; Ward, 2012 \\
\hline Unit quality & $\begin{array}{l}\text { Formal renters: high } \\
\text { (access to services) } \\
\text { Informal renters: low (less access) }\end{array}$ & $\begin{array}{l}\text { Associated with high levels of } \\
\text { overcrowding (because secondary } \\
\text { housing units with expanding } \\
\text { households) } \\
\text { Sharers often in poorer housing } \\
\text { conditions than parents (on site) }\end{array}$ & $\begin{array}{l}\text { Eyre, 1972; Hanson, 1975; } \\
\text { Blanco et al., 2015; Stiphany, 2019; } \\
\text { Edwards, 1982; Ward et al., 2015, } \\
\text { Jiménez \& Camargo, } 2015\end{array}$ \\
\hline Other & $\begin{array}{l}\text { Possibly a rising number of } \\
\text { elderly (especially old men) }\end{array}$ & & $\begin{array}{l}\text { Gilbert, 1999; Ward, 2012; } \\
\text { Varley } 1993\end{array}$ \\
\hline
\end{tabular}

Source: Table compiled by the authors from the literature. 
Table 3. Rental and sharing dwelling characteristics.

\begin{tabular}{|c|c|c|c|}
\hline $\begin{array}{c}\text { Dwelling } \\
\text { characteristics }\end{array}$ & Rental units & Sharer units & References \& Sources \\
\hline Local names & $\begin{array}{l}\text { Vecindades (Mexico) } \\
\text { Cortiços } \text { (Brazil) } \\
\text { Conventillos (Ecuador/Chile) } \\
\text { Cités } \text { (Chile) } \\
\text { Some small apartments for better-off \& speculative } \\
\text { pocket gentrification in older consolidated } \\
\text { settlements ( } 2+\text { bedroom plus integrated } \\
\text { private services) }\end{array}$ & $\begin{array}{l}\text { Allegados }(\text { Chile) } \\
\text { Arrimados (Mexico) }\end{array}$ & $\begin{array}{l}\text { Lewis, 1966; Gilbert, 1991; } \\
\text { Kowarick, 1994; Ward, 1998; } \\
\text { Bonomo \& Mondragon, 2013; } \\
\text { Blanco et al., 2014; Avilés et al., } \\
\text { 2015; Ward et al., 2015; } \\
\text { Consejo Nacional de la Cultura y } \\
\text { Las Artes, La ruta del Cite, Chile; } \\
\text { Centro de Investigación social } \\
\text { (CIS) Chile, } 2017 .\end{array}$ \\
\hline Location & $\begin{array}{l}\text { City center-traditional rooming houses, } \\
\text { converted C18 \& C19 mansions; } \\
\text { C20 constructed } \\
\text { - Intermediate ring and sometimes periphery } \\
\text { also (older consolidated informal settlements) } \\
\text { - } \quad \text { Periphery and peri-urban (rentals of vacant } \\
\text { - } \quad \text { housing social interest housing estates) }\end{array}$ & $\begin{array}{l}\text { Varies, } \\
\text { In separate own home/dwelling } \\
\text { on lot (Mexico) or upper floor } \\
\text { (Lima) or with on-site petty } \\
\text { landlord (Bogotá) }\end{array}$ & $\begin{array}{l}\text { Eyre, 1972; Gilbert, 1991; } \\
\text { Ward, 1998; Clarke, 2006; } \\
\text { Blanco et al., 2014; } \\
\text { Howard, } 2019\end{array}$ \\
\hline Size & $\begin{array}{l}\text { Small one or two roomed \& cramped, } \\
\text { but not necessarily overcrowded } \\
\text { individually (because of small families). } \\
\text { But variations here-overcrowding } \\
\text { does occur. }\end{array}$ & $\begin{array}{l}\text { Small; associated with high } \\
\text { levels of overcrowding } \\
\text { (because secondary housing } \\
\text { units with expanding households) }\end{array}$ & $\begin{array}{l}\text { Gilbert, 1991; } \\
\text { Ward, 1998; } \\
\text { Clarke, 2006; } \\
\text { Blanco et al., } 2014\end{array}$ \\
\hline Services & 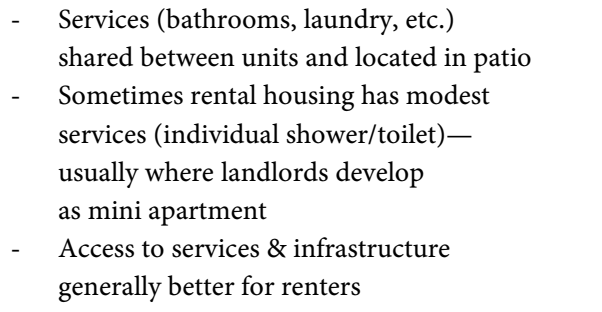 & Depends on owner situation & $\begin{array}{l}\text { Clarke, 2006; } \\
\text { Blanco et al., 2014; } \\
\text { Ward et al., } 2015\end{array}$ \\
\hline Quality & $\begin{array}{l}\text { Often heavily dilapidated \& distressed } \\
\text { and less good building materials }\end{array}$ & Varies & $\begin{array}{l}\text { Eyre, 1972; Hanson, 1975; } \\
\text { Blanco et al., 2014; } \\
\text { Ward et al., 2015; } \\
\text { Stiphany, } 2019\end{array}$ \\
\hline
\end{tabular}

Source: Source: Table compiled by the authors from the literature.

\section{User Trajectories to Renting and Sharing Opportunities}

$\underline{\text { Renting to Live; Rentals for Work }}$

Short-term Renters are generally small families and young couples who are not ready or financially able to enter into the ownership market. This can include both low-income and middle-class workers who have either migrated into urban centers more recently for better economic opportunities, or are city born, often coming from the same neighborhood in which they have lived most or all of their lives and have fled the family nest. Students are also frequent rentersacross a range of rental types depending upon income and work opportunities. Rental housing provides a temporary housing option before the family grows and, maybe begins to think about owning a home. 
Longer-term Renters are found in both low- and lower-middle income neighborhoods where renters have settled into renting or sharing and whose dwelling environment is generally of better quality (Edwards, 1982). Often, too, they do not have strong aspirations or the financial wherewithal to commit to ownership options. This group (lower-middle class renters) is under researched, and their aspirations and trajectories are less well understood. They have larger families, comprise multiple age groups, and are generally okay with rental housing - as long as it caters to their needs. It can include both elderly and younger couples who are renting long-term for different reasons. Middle-class dwellers can also be long-term renters not willing to commit to ownership because of the nature of their work, because they are financially unable to own, or because they need the flexibility to be able move at short notice.

Second and Third Generations. One of the major challenges in the Latin American and Caribbean region are the second and third generation cohorts living in low-income communities whose grandparents and parents migrated to urban centers for better opportunities, but were not able to move up the socioeconomic ladder. These are usually younger demographics who, while they have sometimes been attracted to the new opportunities for ownership in the low-income mass housing estates (Jiménez et al., 2019), ${ }^{5}$ few have had any interest in self-building in the current urban periphery copying the trajectory of their parents. Rather, being city and barrio born, they remain attracted to life in the urban core and intermediate ring close to their work, markets and amenities.

Several common trajectories among renters can be identified:

1) Where the landlord enters into a petty-landlord tenant relationship in her own dwelling or on his lot. Countries vary in the propensity to which a landlord allows someone to rent in his own housing space. In Bogotá, for example, it is quite common (Gilbert 1983; Gilbert \& Ward, 1985); while in Mexico City it is relatively rare (Ward, 2012).

2) In these latter cases (Mexico), petty-landlord-tenant arrangements are more likely to be developed in a separate location from the owner's home site: in a second lot or dwelling in the same or an adjacent barrio. Where it is a vacant dwelling (sometimes a single dwelling unit that the landlord no longer uses), the owner sub-lets usually to a better-off working-class family who can afford the higher rent (Gough, 2018). Alternatively, the landlord develops a small tenement-type arrangement of anything between five to ten single room or very small units, usually with common shared services (showers, W.C., etc.). These rentals target the very low-income populations (Jiménez \& Camargo, 2015). Several hybrid arrangements of dwelling extension and subdivision scenarios have been closely documented in São Paulo's cortiços (Stiphany, 2019; Stiphany, Ward, \& Palazzi, 2020).

${ }^{5}$ Focus groups conducted by Jiménez and her colleagues indicated that there was a gender split among couples: men were more interested in moving to the periphery, while women preferred to continue renting or sharing in order to stay close to their family in the colonias (barrios) in which they had grown up. 
3) Matriarchal/Matrifocal Households. Many informal settlements in the LAC region, and especially in the Caribbean, are matrifocal and female-headed. In Kingston, Jamaica for example, matrifocal households are common both in outer squatter settlements and especially in the inner-city yards and tenements (Tindigarukayo, 2002, 2014). Female headed households often have the burden having to work, taking care of the house, and raising their children all at once, without substantive help from male family members. It is not unusual to find that a single rental tenement has several female headed households which provide social support and mutual child care.

4) Alongside scenarios 1 and 2, rental opportunities may also be created for commerce or for workshops, especially given that the informal economic sector is such a large part of the contemporary work force and activities. Small commercial rentals are especially likely to be created on street corners, or close to main thoroughfares. They vary from small single room stores (Photo 4(a)), to small (one-two) room café/restaurants, to single room lockups (tortillas or bread production, to larger space workshops (talleres Photo 4(b)).

5) Sharing Trajectories

As described above, sharing arrangements usually emerge organically around close familial and household arrangements. As adult children sharing with their parents and siblings, they may share some of the household's running costs; have their own metered electricity account (if they live separately on the lot); or even pay a nominal "rent". However, the important construct here is that they do not perceive themselves as renters, nor should they. Sharers add to the complexity of the universe of non-owners, and their household dynamics and accommodation needs are even less well understood than those of renters, but often occupy one of the following scenarios:

a) They sometimes comprise short- and medium-term arrangements where more recently arrived migrants live with kinsmen (the terms vary by country: arrimados, allegados, etc.). Occupying a single room, they may share costs but are not strictly renting since there is a socio/cultural commitment to help a kinsman as she seeks work; studies at college; undertakes work training, etc. Thus, these are temporary arrangements. In many other respects, they may resemble renters (young, singletons, etc.).

b) Adult children of the original pioneer self-builders are the more common form of sharers, especially within households of the 1960s parent generation, where families were often large with several siblings. While the parents are invariably settled in their homes for life (Gilbert 1999; Ward 2012), the adult children who grew up in the family home are often quite mobile: leaving the family nest as they seek work; get married, have families of their own, etc. Some also return to the family home (often daughters with their own children after divorce or desertion, cases of domestic violence, etc.) This "churn" provides the fuel (supply) into many of the renting opportunities described above. 


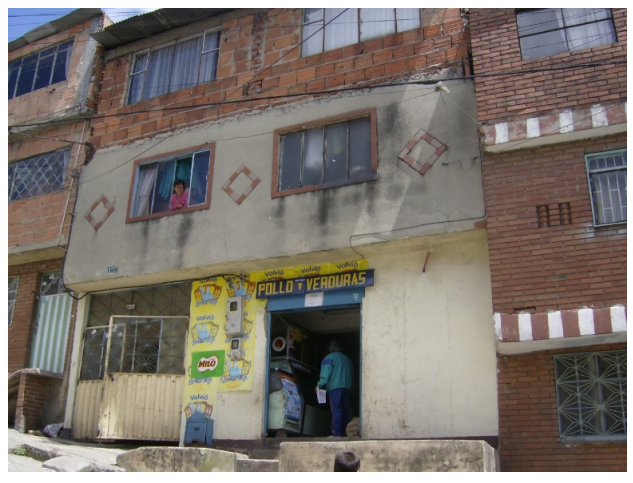

(a)

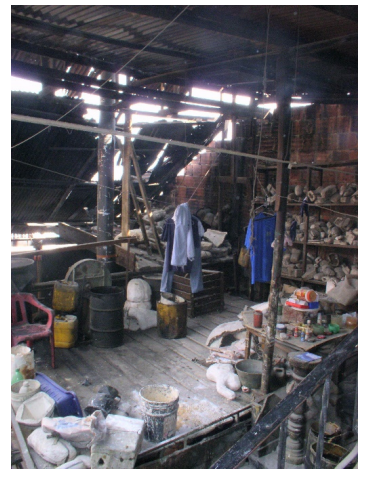

(b)

Photo 4. Typical rentals for commerce and production: In consolidated informal settlements, Bogotá. Left, (a): Three story home with rental general store ("Chicken and vegetables”); Right (b): Ceramics and Stucco “factory”/workshop [Author's photos].

c) Other adult children share in the long-term, occupying rooms or a floor of the dwelling, or a separate room(s) on the lot, either because it is more convenient and low cost (saves money), or because they harbor expectations that, ultimately, they will become owners through inheritance, even if as a part share with their siblings. In these cases, they often live in one or two rooms set apart from their parents in the lot; or occupy space in the main dwelling unit and share a kitchen. Sharing presents major challenges such as lack of privacy, and data suggest that the quality of the second and third housing units on the lot are of poorer quality than the primary dwellings, with higher levels of overcrowding since they comprise a young family often living in a single room (Ward \& Jimenez, 2011; Jiménez, 2014; Ward, Jiménez, \& Di Virgilio, 2015).

d) Sharing may also evolve as a deliberate housing strategy, where the parents/owners construct upper floors for one or more of their adult children. This is notable in Lima where there is a tradition of thinking about who owns "los aires" (the vertical development rights) (see Rojas et al., 2015).

\section{The Lack of Policy Traction for Renting by Latin American and Caribbean Governments}

Despite the ongoing demand for non-ownership housing and several attempts by a small number of researchers to advocate for rental housing policies for low-income communities (Gilbert, 2003; Blanco et al., 2013, 2014; Jiménez \& Camargo, 2015), there has been little traction for non-ownership policies across Latin America. Why so?

We can speculate about the possible overlapping reasons. First, the 50 years of dominance of homeownership policies and the neoliberal agenda have tended to drown-out alternative low- income tenure considerations. Homeownership is still equated with social stability, positive patterns of consumption that contribute to GDP growth, upward social mobility, such that financial institutions are invariably more inclined towards more profitable homeownership assistance rather 
than renting. Second, there is a stigmatization that often surrounds renting among the poor, associated as it often is, with marginalized communities and heavily dilapidated neighborhoods and housing structures often stereotyped as 'slums' (Mayne, 2017). Third, unlike earlier research about slums or the intense research interest that was generated about the expansion of post-1960s informal settlements and self-help building, relatively few researchers and academics have shown much interest in studying rental housing. This means that informal renting is poorly understood, and published research is rarely picked up by governments, not least since the literature has not been able to adequately encapsulate the range and depth of rental practices in the region.

A fourth reason is that the lesser-studied realm of sharing adds confusion: are sharers just special case "renters", "sometime renters", or "extensions of ownership", given that they are increasingly second and third generation households with inheritance expectations (Grajeda, 2015; Jiménez et al., 2019). Sharer trajectories and aspirations are different to renters, but to date those differences remain poorly understood. Finally, understanding about, and planning for, heterogeneity and multiplex trajectories is difficult. These inner-urban neighborhoods comprise multiple constituencies: long-term owners with title; others with "clouded" titles; newer owners; "gentrifiers"; female-headed and matrifocal households; multi-generational households; and, as we have observed, a large array different types of rental accommodation types including commercial and workplace rentals. This presents challenges for policy diagnosis, and for being able to identify any one policy or set of policies that are sufficiently convincing or politically attractive, whether it be rent control, rental housing production, financing mechanisms, or even a voucher system as in the United States and in Chile, for example. Politically speaking, policies to address low-income renting and sharing are not "sexy" or readily amenable to garnering political support.

Moreover, in today's urban planning environments, policy interventions need to be holistic and multiplex and are, therefore, inherently difficult to develop and, especially, to implement. In the past holistic planning in Latin America was easier since these were often authoritarian governments which made wholesale clearance and regeneration a possibility. However, in today's more democratic and nuanced planning environment in which Rights to the City are widely espoused and recognized, such clearance policies are rarely feasible (not to mention undesirable).

\section{The Potential Role of Supply-Side Stakeholders}

Despite these difficulties, we believe that government prioritization of rental policies is essential. As Blanco et al. (2014) have described, in order for the demand of side of renter and sharer needs to be met formally (or informally) in the future, policy making will need to understand and engage with the interests of actors who, largely informally in the past, have been engaged in the supply of low-income housing opportunities for non-ownership. 
Before turning to specific policy approaches and scenarios, we first outline the principal actors who have the potential to significantly increase the supply of rental housing.

1) The Private Sector-especially landlords

- The private sector has an important role to play, both at the larger and smaller scales. Both large-scale and small-scale landlords need to be incentivized to provide more rental housing options.

- Public-private partnerships can be formed to ensure high-quality dwellings and consultation to self-builders. The combination of private sector expertise and funding, and public sector regulation and policy can create more interest in the rental market.

- Much can be learned from the informal sector on rental tenures and types. Governments need to capitalize on these practices and regularize such processes to attain the quality standards found in the formal sector.

- Encouragement of owners in informal settlements who wish to open up renting opportunities either in their own dwelling environments or in petty landlord arrangements on small tenements. In mass social-interest housing estates owners may choose to rent instead of defaulting and abandoning their investments.

2) The Public Sector

- The starting point for rental market prioritization almost certainly needs to come from government, both at the central and local level. The central government has the ability to set the tone for future housing policies, and so renting needs to become a vital focal point, starting with its de-stigmatization relative to ownership.

- Local governments in cities and towns can play a role by providing various incentives such as tax breaks and financial subsidies to the private sector and non-governmental actors to build more rental housing.

- The aim for these governments needs to be able to strike a balance between landlord and renter needs. Regulation and monitoring need to play an inherent role throughout these processes to overcome the negative outcomes historically associated with renting. This is to ensure that landlords are not taking advantage of tenants and vice versa.

- The government also needs to differentiate between both short-term and long-term, and between low-income and middle-class rental markets, in order to cater to different needs.

3) Financial Agencies

- Financial agencies and banks have historically been more inclined to providing financial schemes for homeownership. Public-private partnerships need to incorporate the role of these agencies and promote financial assistance for renters. This can be done by offering more security in renting loans and providing more incentives to the financial sector to also accommodate renters and sharers. 
4) NGOs

- Local nonprofits and NGOs are generally more in tune with local needs. The public and private sector need to incorporate this expertise into the housing development processes.

- NGOs can also provide alternative practices such as cooperatives that encourage collective ownership and renting, allowing for more flexibility and autonomy for low-income communities.

- NGOs also play a vital role in advocating for rental housing, which can positively contribute to shifting the negative narrative on such alternative housing.

5) International Agencies

- Much related to the role of NGOs, international agencies play a vital role in the global discourse around renting and can help in advocating for it as a viable housing option.

- Agencies like the International Monetary Fund, the World Bank or the United Nations can incentivize LAC governments to promote rental housing production in their countries.

- They also need to encourage more localized research in the region to thoroughly understand the tenets of the rental housing market.

\section{Regional Policies to Promote Renting and to Accommodate Sharing}

Based upon a better understanding of these various actors, it is important to delineate policy options for the various stakeholders. The materials gathered as part of our five country case studies (Antequera et al., 2020) build upon four main secondary sources: 1) Gilbert's (2003) United Nations monograph; 2) Blanco's (2013) call for rental policies that "make sense"; and 3) that same author and his co-editors volume of renting in Latin America and the Caribbean (Blanco et al., 2014); and 4) the nine country study of the Latin American Housing Research Network of consolidated informal settlements, and policies of housing and community rehabilitation (rehab). ${ }^{6}$ In Table 4 we outline some of the supply side policies and stimuli that would help to increase the production of new rental accommodation opportunities on the one hand, alongside policies and approaches that would improve the security and living conditions of renter households (the demand side[see Blanco et al., 2014: Ch. 13]).

Promoting and Incentivizing Renting as an Inherent Part of Urban Develop$\underline{\text { ment }}$

An objective of policies should be to seek traction in the rental housing market. The starting point is for government policies to move away from owner occupation as a universal goal (Gilbert, 2003; Blanco et al., 2014).

${ }^{6}$ https://www.lahn.utexas.org/. See also: Ward, P. M., Jiménez, E. R., \& Virgilio, M. M. (2015). Housing policy in Latin American cities. A new generation of strategies and approaches for 2016 UN-HABITAT III. Routledge. 
Table 4. Policies to promote the supply side of rental housing.

\begin{tabular}{|c|c|c|c|}
\hline Action/Policy Idea: Renters & Target Population/Institution & Comments & Source/Reference \\
\hline Supply Side & & Chapter 3 of Blanco et al. & Blanco et al., 2014 \\
\hline $\begin{array}{l}\text { Promote production } \\
\text { and supply of rental } \\
\text { housing opportunities: }\end{array}$ & Low-income owners & $\begin{array}{l}\text { "Plan Terrazas", Colombia supports to expand } \\
\text { dwellings (and improve quality); but also } \\
\text { encouraged renting as a partial }\end{array}$ & $\begin{array}{l}\text { Jimenez \& } \\
\text { Camargo, } 2015\end{array}$ \\
\hline $\begin{array}{l}\text { Decrease } \\
\text { favoring ownership }\end{array}$ & Govt policies & $\begin{array}{l}\text { Move away from idea that owner occupation } \\
\text { is a universal goal... }\end{array}$ & $\begin{array}{l}\text { Gilbert; 2003; } \\
\text { Blanco et al., } 2014\end{array}$ \\
\hline Buy to let (e.g. UK) & $\begin{array}{l}\text { Promoted by public sector } \\
\text { target private sector investors: }\end{array}$ & $\begin{array}{l}\text { Need to ensure that investment return on a par or } \\
\text { greater than other investments (tax framework below) }\end{array}$ & Blanco et al., 2013 \\
\hline Tax incentives (a) & Informal settlement landlords & $\begin{array}{l}\text { Probably not paying taxes so tied to regularization; } \\
\text { but would be waiver or tax reduction on incomes }\end{array}$ & $\begin{array}{l}\text { Blanco et al., } 2013 \\
\text { Gilbert; } 2003\end{array}$ \\
\hline Tax incentives (b) & $\begin{array}{l}\text { Larger scale formal } \\
\text { sector developers }\end{array}$ & Tax incentives; Tax Credits & Blanco et al., 2013 \\
\hline Grants and subsidies & $\begin{array}{l}\text { Landlords smaller } \\
\text { scale landlords, } \\
\text { petty landlord-tenant } \\
\text { arrangements }\end{array}$ & $\begin{array}{l}\text { Financial support tied to expanding and/or improving } \\
\text { quality dwelling units on or off site. Maybe loans } \\
\text { that are forgiven; or low interest subsidies. } \\
\text { Aim is to promote rental opportunities, } \\
\text { and improve quality of accommodations. }\end{array}$ & Blanco et al., 2013 \\
\hline $\begin{array}{l}\text { Urban } \\
\text { development planning }\end{array}$ & $\begin{array}{l}\text { Developers; Private public } \\
\text { partnerships; } \\
\text { Housing Coops etc. }\end{array}$ & $\begin{array}{l}\text { Urban development concessions } \\
\text { (planning permissions; land pooling, land swaps etc.); } \\
\text { mixed residential development programs etc., }\end{array}$ & Blanco et al., 2013 \\
\hline Relax Building standards & Landlords, Local Govts. & $\begin{array}{l}\text { Often standards are too high and minimum standards } \\
\text { will do. But must be measured against risk } \\
\text { (earthquakes; landslides etc.) } \\
\text { Appropriate regulatory environment. }\end{array}$ & Gilbert 2003 \\
\hline $\begin{array}{l}\text { Expand Political Support } \\
\text { and Incentives to NGOs } \\
\text { and Housing Cooperatives }\end{array}$ & $\begin{array}{l}\text { Housing Cooperatives; } \\
\text { NGOs }\end{array}$ & $\begin{array}{l}\text { Reduce red tape and regulatory restrictions; provide } \\
\text { credit and financial supports. Goal is to expand rental } \\
\text { housing as a platform for short and medium-term } \\
\text { renters (aspiring to become owners) }\end{array}$ & Blanco et al., 2013 \\
\hline $\begin{array}{l}\text { Encourage a social } \\
\text { housing sector }\end{array}$ & Govt. & $\begin{array}{l}\text { That targets renters primarily } \\
\text { (as in Europe traditionally): } \\
\text { Create opportunities for renting in "failing" } \\
\text { mass social interest housing at the periphery }\end{array}$ & $\begin{array}{l}\text { Gilber,2003 } \\
\text { Jiménez, } 2014\end{array}$ \\
\hline $\begin{array}{l}\text { Insurance and Support } \\
\text { to landlords }\end{array}$ & $\begin{array}{l}\text { Petty landlords in } \\
\text { informal settlements }\end{array}$ & $\begin{array}{l}\text { Support \& incentives for registration of contracts } \\
\text { with tenants that also provide safeguards to evict; } \\
\text { maybe gain compensation for damages etc. }\end{array}$ & $\begin{array}{l}\text { Blanco et al., } 2013 \\
\text { Gilbert; 2012; } \\
\text { Gilbert; } 2003\end{array}$ \\
\hline $\begin{array}{l}\text { Insurance and } \\
\text { Support to landlords }\end{array}$ & $\begin{array}{l}\text { Landlords in formal sector; } \\
\text { Insurance companies Rental } \\
\text { Guarantee Insurance } \\
\text { (e.g. FGA, Uruguay); } \\
\text { Gov and NGO institutions. }\end{array}$ & $\begin{array}{l}\text { Promote participation of insurance schemes that will } \\
\text { pay land lord for income lost through the period of } \\
\text { repossession after delinquency of payments. } \\
\text { Reduce transaction costs of renting and repossession }\end{array}$ & Blanco et al., 2013 \\
\hline $\begin{array}{l}\text { Create Dispute } \\
\text { Mechanisms for } \\
\text { handling conflict }\end{array}$ & $\begin{array}{l}\text { Renters \& Landlords; NGOs; } \\
\text { University Legal Clinics etc. }\end{array}$ & $\begin{array}{l}\text { Aim is to provide non-govt and non-judicial } \\
\text { mechanisms that can: a) provide appropriate } \\
\text { information to all parties; and b) can provide } \\
\text { mediation and orientation services }\end{array}$ & $\begin{array}{l}\text { Blanco et al., } 2013 \\
\text { Gilbert; } 2003\end{array}$ \\
\hline Rent Controls & Landlords \& Tenants & $\begin{array}{l}\text { Sets ceiling for rents \& permitted periodic } \\
\text { increases (tied to inflation); } \\
\text { Actions for modify existing (uneconomic) } \\
\text { rent control agreements (may "rent to own"? }\end{array}$ & $\begin{array}{l}\text { Blanco et al., } 2013 \\
\text { Gilbert, } 2003\end{array}$ \\
\hline
\end{tabular}




\section{Continued}

\begin{tabular}{|c|c|c|c|}
\hline $\begin{array}{l}\text { Expansion of } \\
\text { self-built rentals }\end{array}$ & Informal settlement landlords & $\begin{array}{l}\text { Encourage expansion of rooms in self building } \\
\text { (residence and commerce)_for rent and } \\
\text { income earning }\end{array}$ & Gilbert, 2003 \\
\hline Micro credits & Landlords & $\begin{array}{l}\text { Encouraging landlords to add renting into } \\
\text { their dwelling units; especially when tied to } \\
\text { regularization and upgrading programs }\end{array}$ & $\begin{array}{l}\text { Gilbert, } 2012 b \\
\text { Gilbert, } 2003\end{array}$ \\
\hline Housing Rehab Programs & Landlords (and even tenants) & $\begin{array}{l}\text { As part of rehab include improving spaces that } \\
\text { might become rental units; and/or convert that of } \\
\text { adult of children who have left }\end{array}$ & $\begin{array}{l}\text { Jimenez \& } \\
\text { Camargo, } 2015 \\
\text { Gilbert, } 2003\end{array}$ \\
\hline $\begin{array}{l}\text { Campaigns to improve } \\
\text { awareness of the } \\
\text { importance of renting }\end{array}$ & Govts. NGOs; General Public. & $\begin{array}{l}\text { Publicity and information campaigns to promote } \\
\text { understanding of renting and dispel stereotypes } \\
\text { about landlordism and rental housing as a problem. } \\
\text { Debunking the myth (Gilbert) Social mobilization } \\
\text { (rent associations; etc.) }\end{array}$ & $\begin{array}{l}\text { Jimenez \& } \\
\text { Camargo, } 2015 \\
\text { Gilbert, } 2003\end{array}$ \\
\hline $\begin{array}{l}\text { Focus upon vacant } \\
\text { housing and vacant lots }\end{array}$ & $\begin{array}{l}\text { Landlords in the center; } \\
\text { Informal landlords } \\
\text { (often) in the periphery }\end{array}$ & $\begin{array}{l}\text { Programs of eminent domain; sequestration to } \\
\text { convert vacant builds for reuse (renting or otherwise) }\end{array}$ & $\begin{array}{l}\text { Jimenez \& } \\
\text { Camargo, } 2015\end{array}$ \\
\hline
\end{tabular}

Source: Table compiled by the authors from the literature.

Incorporating rental housing into the urban development planning process at the macro level would be one way forward. Many current planning practices around the world are focused on urban renewal and "New Urbanism" which promote dense, diverse, and mixed-use land development. Given the limited resources that Latin American governments can leverage for new housing developments there needs to be a focus on community and housing rehabilitation which is not achievable without the consideration of renting as an integral part. The aim should be a healthy mix of owned, rented, and shared housing units within one neighborhood that would minimize gentrification and displacement. This will foster community integration and reduce the marginalization of low-income (usually informal) neighborhoods.

The incentivizing process needs to cater to the different actors on the production (supply) side of this process. This includes incentivizing both large-scale and small-scale landlords: through tax incentives, financial assistance and insurance policies that reduce the burden of rental production on developers and individual households. The aim would be to ensure that the return on investment is equally or more attractive compared to other investments. In addition, relaxing building standards and red tape should be incorporated into such attraction schemes, while ensuring a healthy balance between regulation and autonomy. For more informal, petty landowners, the regularization process should be combined with tax breaks and subsidies to encourage the conversion from informal to formal tenure (Gilbert, 2003; Blanco, 2013).

The public sector can also encourage more partnerships between NGOs, the private sector, and financial agencies in order to create more options for cooperatives and communal ownership and renting. This allows for petty landlords to 
come together and share the burden of building new units or upgrading older units. The public sector also needs to consider going back to providing affordable social rental housing to low-income communities. In order to avoid the dilapidation of such neighborhoods, it is important to incorporate partnerships with the private sector and environmental advocates that can ensure higher quality and sustainable development, which again serves global agendas surrounding contemporary urban planning (Table 5).

Table 5. Policies to promote the demand side of rental housing.

\begin{tabular}{|c|c|c|c|}
\hline Action/Policy Idea: Renters & Target Population/Institution & Comments & Source/Reference \\
\hline Demand Side & & Chapter 3 of Blanco et al., 2014 & Blanco et al., 2014 \\
\hline Rent controls (1) & $\begin{array}{l}\text { Govt institutions; NGOs \& } \\
\text { mediation agencies; landlords; } \\
\text { tenants living in rent } \\
\text { controlled accommodation }\end{array}$ & $\begin{array}{l}\text { Where renters are occupying properties that } \\
\text { enjoy outdated and grossly uneconomic rents } \\
\text { promote incentives to "buy out" or to flip to an } \\
\text { economic rent (rent to own); balloon payment by } \\
\text { landlord (incentive) to flip to economic rent etc. }\end{array}$ & $\begin{array}{l}\text { Blanco et al., } 2013 \\
\text { Gilbert, } 2003\end{array}$ \\
\hline Rent controls (2) & Renters primarily & $\begin{array}{l}\text { At contract, guarantee permitted } \\
\text { levels of rental periodic rent increases. }\end{array}$ & $\begin{array}{l}\text { Blanco et al., } 2013 \\
\text { Gilbert, (2012b) } \\
\text { Gilbert, } 2003\end{array}$ \\
\hline $\begin{array}{l}\text { Complementary demand } \\
\text { side incentives ( } 1 \text { ) }\end{array}$ & Institutions to Renters & $\begin{array}{l}\text { Redirect rental subsidies to those most in } \\
\text { need and prioritized: elderly female } \\
\text { headed households; students etc. }\end{array}$ & Blanco et al., 2013 \\
\hline $\begin{array}{l}\text { Complementary demand } \\
\text { side incentives ( } 2 \text { ) }\end{array}$ & $\begin{array}{l}\text { Institutions and programs like } \\
\text { Section } 8 \text { (USA) }\end{array}$ & $\begin{array}{l}\text { Subsidy/vouchers that cover the difference } \\
\text { between a } \% \text { of household income ( } 30 \%) \\
\text { and the market rent in the area }\end{array}$ & $\begin{array}{l}\text { Blanco et al., } 2013 \\
\text { Gilbert, } 2003\end{array}$ \\
\hline Vouchers (3) & Renters & Vouchers to encourage/support renting & Blanco et al., 2013 \\
\hline $\begin{array}{l}\text { Complementary demand } \\
\text { side incentives }(4)\end{array}$ & $\begin{array}{l}\text { Government policy and fiscal } \\
\text { institutions: }\end{array}$ & $\begin{array}{l}\text { Balance tax and renting policies between } \\
\text { ownership and renting incentives } \\
\text { (problem is that ownership heavily favored) }\end{array}$ & $\begin{array}{l}\text { Blanco et al., } 2013 \\
\text { Gilbert, } 2003\end{array}$ \\
\hline Grants and subsidies & $\begin{array}{l}\text { Informal settlement owners } \\
\text { and sharers with long term } \\
\text { aspirations to remain on lot }\end{array}$ & $\begin{array}{l}\text { Financial support tied to expanding and/or } \\
\text { improving quality dwelling units on or off site. } \\
\text { Maybe loans that are forgiven; or low interest } \\
\text { subsidies. Aim is to "regularize" sharing } \\
\text { opportunities, and improve quality of } \\
\text { accommodations especially for } 2^{\text {nd }} \text { and } 3^{\text {rd }} \text { units. } \\
\text { Ensure that subsidies do not threaten to } \\
\text { escalate rents (rent hikes, etc); }\end{array}$ & $\begin{array}{l}\text { Blanco et al., } 2013 \\
\text { Jimenez \& } \\
\text { Camargo, } 2015\end{array}$ \\
\hline $\begin{array}{l}\text { Increase Security of } \\
\text { tenancy arrangements }\end{array}$ & Renters and Landlords & $\begin{array}{l}\text { Incentivize demand. Promote contracts that } \\
\text { recognize rights and obligations between } \\
\text { the parties, and which provide appropriate } \\
\text { security and guarantees to both parties }\end{array}$ & $\begin{array}{l}\text { Blanco et al., } 2013 \\
\text { Gilbert, } 2003\end{array}$ \\
\hline $\begin{array}{l}\text { Improve understanding and } \\
\text { policies that recognize and } \\
\text { respond to the segmented } \\
\text { nature of the rental market in } \\
\text { both formal and informal sectors }\end{array}$ & $\begin{array}{l}\text { Renters low income } \\
\text { Short term renters moderate } \\
\text { income; } \\
\text { Students; } \\
\text { Migrant workers } \\
\text { Elderly (singletons and couples); } \\
\text { Disabled or health challenged; }\end{array}$ & $\begin{array}{l}\text { The goal here is to increase the supply of } \\
\text { housing to meet the often-unrecognized } \\
\text { demand from specific groups, many of whom } \\
\text { only want short term (often small) rental } \\
\text { housing, either by virtue of work; or because } \\
\text { they are moving up the ladder to ownership } \\
\text { or family size formal renting. }\end{array}$ & $\begin{array}{l}\text { Blanco et al., } 2013 \\
\text { Jimenez and } \\
\text { Camargo, } 2015\end{array}$ \\
\hline
\end{tabular}

Source: Authors' compilation from the literature and from Antequera et al., 2020. 
Encouraging Self-Building Processes That Embrace Renting and Sharing

Much can be learned from informal settlements about how to create and support rental and sharing options for low-income communities. Self-building and communal living have been an inherent part of the urban fabric of most countries in the region and allows a level of autonomy that more formalized processes cannot offer. Under this umbrella, governments should incentivize formalized self-building and sites-and-services practices that are regulated and follow land and housing development standards, all the while allowing petty landlords to construct dwellings that cater to their individual needs both on and off site. Such households can also be incentivized to rent and sublet to other low-income communities as a form of return on investment and support for communal living. This helps informal settlements maintain their communal identities, and facilitates household agency to formally own, rent or share their dwellings with family, friends and similar demographics in need. Again, the public sector needs to consistently monitor and regulate these processes to avoid degradation. Abandoned and vacant lots and dwellings should also be tied into these schemes.

\section{$\underline{\text { Balancing Tenant and Landlord Needs and Interests }}$}

Historically, rent control policies and political instability have contributed to poor tenant-landlord relationships. On the one hand, tenants have been able to usurp possession of rented dwellings from the owners; while on the other, landlords have evicted tenants at will. Therefore, a balanced approach to tenure and landlord security needs to be in place where all roles and responsibilities are put into written contracts. Insurance schemes need to be incorporated into housing contracts to ensure security for both parties (Blanco, 2013). The emphasis of the public sector should be to monitor these processes consistently in order to avoid any party taking advantage of the other. Renting price subsidies should be provided to low-income dwellers, while implementing periodic rent increases that assist the landlords. Such balanced structures will encourage more owners to rent out their dwellings and provide the security needed for low-income communities, preventing them from settling informally elsewhere. Rent-to-own schemes should also be offered as an option to those tenants who are renting from landlords, but always balanced to allow for flexibility, autonomy and appropriate regulation.

$\underline{\text { Responding to Different Segments of Populations }}$

An important part of the policy discourse is to recognize the different needs of various demographics found in the rental market. There is a distinction between long-term and short-term renters to which the supply-side actors must cater. Renting should not only be limited to a short-term option when there is a clear demand by both low-income and middle-class households for long term contracts.

As we have observed, today there are second and third generations living in what are inner-urban neighborhoods that were created informally by their parents and grandparents some 30 to 40 years earlier. These populations have grown 
up with such accommodation and seen firsthand the creative housing practices their families have engaged in. Therefore, specific policies of inheritance and transfer of tenure provisions should be incorporated into the regularization process. Given that many have resided in these communities all of their lives they deserve both financial and social assistance that grants more permanence and greater security for their various tenurial options in the future.

As noted earlier, many of the households that are particularly vulnerable to degraded or deteriorated housing conditions and informal options are female-led. The public sector, therefore, needs to cater to these needs and offer more financial and building assistance to such households. Subsidies, tax breaks and construction assistance should be prioritized for such households with financial agencies offering equal, if not more, options for women to access loans and both rental and ownership opportunities. Also, centralized sanitation systems and more privacy in dwellings should be arranged for such neighborhoods.

Policies Specific to Sharing

As we have argued, sharing is an important and yet neglected part of the informal housing market. Therefore, policies that cater to sharers and alternative housing options should also be considered. These include the regularization and promotion of wills and legacy arrangements where family members can share and inherit dwelling units under written contracts (Jiménez et al., 2019; Ward, Jiménez, \& Di Virgilio, 2015). These documents can ensure the security of sharers and avoid any potential disputes on who owns what part of the unit, and creating these agreements allows for future building improvements for further renting or sharing. Financial assistance in forms of subsidies, tax breaks or credit options should also be offered to households building additional units to cater to sharers (Jiménez \& Camargo, 2015). The key should be to ensure maintenance of quality and prevention of dilapidation and extremely high densities. These processes, should therefore, be carefully monitored and regulated.

Policies and incentives to assist sharer households who are, for whatever reason, "stuck" (constrained) in living with parents, to be able to leave and move into renting or into ownership. A good example here is in Chile which offers a "Chao Suegra" for allegados and others. ${ }^{7}$ This is a rental subsidy which initially focused on young couples who wanted to break away and live independently from their parents. Even though the coverage of the program has been expanded over the years, the program is limited to a maximum of 8 years, and is conceived as a transition (period) to moving into ownership (Table 6).

In developing policies for both renters and sharers, it important to tie these policies to educational, transportation, employment-based locations and opportunities, health facilities, etc. There needs to be a holistic approach that realizes the intersectionality between class, race, gender and tenure types and the vulnerabilities associated with these constructs.

"Chao suegra" means "goodbye mother in law". Colloquial name of the rental subsidy. https://www.youtube.com/watch?v=aCxKUB4Tlxs. 
Table 6. Policies to attend to the supply and demand sides of sharing.

\begin{tabular}{|c|c|c|c|}
\hline Action/Policy Idea: Sharers & Target Population/Institution & Comments & Source/Reference \\
\hline \multicolumn{4}{|c|}{ Demand Side (but note that Supply and Demand Sides are Intertwined) } \\
\hline & & $\begin{array}{l}\text { Aim is to: } \\
\text { 1) Preempt disputes between legitimate } \\
\text { stakeholders through pre-death } \\
\text { assignment of ownership }\end{array}$ & Jiménez \& Camargo, 2015; \\
\hline $\begin{array}{l}\text { Promote Wills or } \\
\text { Legacy Arrangements }\end{array}$ & $\begin{array}{l}\text { Sharer stakeholders; Sibling } \\
\text { stakeholders; Elderly parents }\end{array}$ & $\begin{array}{l}\text { 2) Provide for clarity of ownership or } \\
\text { residency rights of future owners and } \\
\text { sharers; } \\
\text { 3) to remove obstacles to the incentives } \\
\text { to invest in improvements } \\
\text { and additions, etc. }\end{array}$ & $\begin{array}{l}\text { Ward et al., } 2015 . \\
\text { Grajeda, 2015; } \\
\text { Jiménez et al., } 2019 .\end{array}$ \\
\hline $\begin{array}{l}\text { Promote new types of } \\
\text { shared ownership }\end{array}$ & Sharer stakeholders & $\begin{array}{l}\text { Condominio familiar; } \\
\text { Patrimonio familiar; } \\
\text { Agreed user rights (usufruct); }\end{array}$ & $\begin{array}{l}\text { Donoso, 2018; } \\
\text { Jiménez et al., } 2019 .\end{array}$ \\
\hline \multicolumn{4}{|l|}{ Supply Side } \\
\hline Grants and subsidies & $\begin{array}{l}\text { Informal settlement owners } \\
\text { and sharers with long tern } \\
\text { aspirations to remain on lot }\end{array}$ & $\begin{array}{l}\text { Financial support tied to improving } \\
\text { housing especially for } 2^{\text {nd }} \text { and } 3^{\text {rd }} \text { family } \\
\text { units; with options to tie to future } \\
\text { ownership (shared or otherwise) rights; } \\
\text { And/or for creating rental opportunities } \\
\text { on site (see above) Aim is to improve } \\
\text { quality of accommodations especially } \\
\text { for } 2^{\text {nd }} \text { and } 3^{\text {rd }} \text { units while also } \\
\text { regularizing future ownership. }\end{array}$ & Jiménez \& Camargo, 2015 \\
\hline $\begin{array}{l}\text { Extend regularization and } \\
\text { property registration 1) }\end{array}$ & Owners & $\begin{array}{l}\text { To enable later sub division } \\
\text { and inheritance }\end{array}$ & Jiménez \& Camargo, 2015 \\
\hline $\begin{array}{l}\text { Extend regularization and } \\
\text { property registration 2) }\end{array}$ & Owners primarily & $\begin{array}{l}\text { Allows for credits and supports } \\
\text { to modify the dwelling }\end{array}$ & Jiménez et al., 2019. \\
\hline
\end{tabular}

Source: Authors' compilation from the literature and from Antequera et al., 2020.

However, as we have seen in this paper, notwithstanding the extant research about renting and sharing in Latin America-sometimes accompanied by specific and well-formulated policy proposals - there has been almost negligible implementation. Earlier we speculated briefly about why policies to encourage and protect renting in Latin America have consistently failed to take hold. Understanding why this lack of traction exists is likely to be an important first step in identifying the political and policy environment constraints that will need to be overcome if policies to embrace renting and sharing are to move forward in the future.

To underscore our argument throughout this paper: there is an urgent need for further research on renting and sharing in the region. Exploration and dissection of the questions and challenges that we have outlined in this paper will help to establish a clearer understanding of the nature of rental and shared housing arrangements, and will enable experts to recommend better solutions and approaches to the problems and challenges faced by these communities. 
However, as unfortunately appears to be the case to date, such research will count for little unless national governments and city administrations provide greater political and economic support for non-ownership policies, especially those targeting the lower-income migrant and city-born second and third generation households. While the scenario of renting and rental markets that predominated in much of the first have of the twentieth century are unlikely to flip back to the future, we are already observing some notable increases in the proportions of non-ownership in Latin American cities generally, and within the older consolidated informal settlements specifically. In the latter, at least, renters and sharers are likely to become the majority of households in the next decade or two. And yet they remain largely absent from the policy-making literature and policy agenda.

\section{Acknowledgements}

Part of the publication costs associated with this paper were covered by Professor Ward's C. B. Smith Sr. Centennial \#1 Chair in US-Mexico Relations, College of Liberal Arts, University of Texas at Austin. “Author's photos” in captions are from Peter Ward.

We also wish to acknowledge the input of fellow graduate students and case study authors: Felipe Antequera, Aabiya Baqai, Grace Einkauf, Jorge Losoya and Kate Murdoch, who formed part of Professor Ward's "Housing Practices and Policies in Latin America” class, Spring 2020 (see Antequera et al., 2020).

We are also grateful to Ricardo Ainslie for introducing us to the Oscar Lewis Archive and for allowing us to use one of the photos from the "University of Illinois Archives: Oscar and Ruth Papers 1944-1976. Dr. Ainslie is the M. K. Hage Centennial Professor in Education, and Director of the LLILAS-Benson Mexico Center, University of Texas at Austin.

\section{Conflicts of Interest}

The authors declare no conflicts of interest regarding the publication of this paper.

\section{References}

Abramo, P. (2019). The Informal COMP-FUSED City: Market and Urban Structure in Latin American Metropolises. Bulletin of Latin American Research, 38, 20-40. https://doi.org/10.1111/blar.12980

Antequera, F., Baqai, A., Einkauf, G., Losoya, J., \& Murdoch, K. (2020). Low-Income Renting and Sharing in Latin American and Caribbean Cities: Towards a Policy Agenda. Working Paper, Austin, TX: The LBJ School of Public Affairs, The University of Texas.

Avilés, P., Isabel, D., Sánchez, S., \& Anabel, X. (2015). El conventillo como tipología de vivienda en el centro histórico de Cuenca. Bachelor's Thesis, Cuenca: Universidad de Cuenca. http://dspace.ucuenca.edu.ec/handle/123456789/22315 
Blanco, A. G. et al. (2013). 10 ideas por las cuales el alquiler es vital para los sistemas de vivienda en America Latina y el Caribe (y 10 ideas para dinamizar el mercado). Washington DC: IDB.

Blanco, A. G., Cibils, V. F., Miranda, A. M., \& Inter-American Development Bank (2014). Fiscal and Municipal Management Division. Rental Housing Wanted: Policy Options for Latin America and the Caribbean.

Bonomo, U., \& Mondragón, H. (2013). Del Conventillo a la vivienda higiénica espacio doméstico, ciudad e instituciones en Santiago de Chile, 1890-1940. Santiago de Chile: Salubridad, Política estatal, Publicaciones.

Centro de Investigación social (CIS) de Techo-Chile (2017).

Clarke, C. G. (1983). Dependency and Marginality in Kingston, Jamaica. Journal of Geography, 82, 227-235. https://doi.org/10.1080/00221348308980404

Clarke, C. (2006). From Slum to Ghetto: Social Deprivation in Kingston, Jamaica. International Development Planning Review, 28, 1-34.

https://doi.org/10.3828/idpr.28.1.1

Consejo Nacional de la Cultura y Las Artes, La Ruta del Cite, Chile.

Correa, J. (2015). ÉnfaCIS \#9: Crecimiento desigual: Viviendas sociales en la periferia. Centro de Investigación social-Techo, Chile. Diefendorf.

Diefendorf, J. M. (1989). Urban Reconstruction in Europe after World War II. Urban Studies, 26, 128-143. https://doi.org/10.1080/00420988920080101

Donoso-Gomez, R. E. (2018). Affordable Condominium Housing. Architecture and the Built Environment, No. 23, 1-298.

Edwards, M. (1982). Cities of Tenants: Renting among the Urban Poor in Latin America. In A. Gilbert et al. (Eds.), Urbanization in Contemporary Latin America (pp. 129-158). Hoboken, NJ: John Wiley.

Eyre, L. A. (1972). The Shantytowns of Montego Bay, Jamaica. Geographical Review, 62, 394. https://doi.org/10.2307/213290

Fainstein, S. S. (2020). Competing Models. Encyclopedia Britannica. https://www.britannica.com/topic/urban-planning/Competing-models

Federal Works Agency (1941). Second Annual Report, Fiscal Year Ended June 30, 1941. Washington DC: U.S. Government Printing Office.

Fogeslong, R. E. (1986). Planning the Capitalist City: The Colonial Era to the 1920s. Princeton, NJ: Princeton University Press. https://doi.org/10.1515/9781400854509

Gilbert, A. (1983). The Tenants of Self-Help Housing: Choice and Constraint in the Housing Market. Development and Change, 14, 449-477. https://doi.org/10.1111/j.1467-7660.1983.tb00161.x

Gilbert, A., \& Ward, P. (1982). Residential Movement among the Poor: The Constraints on Housing Choice in Latin American Cities. Transactions of the Institute of British Geographers, (New Series), 7, 129-149. https://doi.org/10.2307/622218

Gilbert, A., \& Ward, P. (1985). Housing, the State and the Poor: Policy and Practice in Three Latin American Cities. Cambridge: Cambridge University Press.

Gilbert, A. (1991). In Search of a Home: Rental and Shared Housing in Caracas, Santiago and Mexico City. London: UCL Press.

Gilbert, A. (1999). A Home Is Forever? Residential Mobility and Homeownership in Self Help Settlements. Environment and Planning, 31, 1073-1091.

https://doi.org/10.1068/a311073 
Gilbert, A., \& Varley, A. (2002). Landlord and Tenant: Housing the Poor in Urban Mexico. Abingdon-on-Thame: Routledge. https://doi.org/10.4324/9780203036891

Gilbert, A. (2003). Rental Housing: An Essential Option for the Urban Poor in Developing Countries. Nairobi: UN-HABITAT.

Gilbert, A. (2012a). Private Rental Landlords. In S. Smith et al. (Eds.), The International Encyclopedia of Housing and Home (pp. 381-386). Amsterdam: Elsevier. https://doi.org/10.1016/B978-0-08-047163-1.00463-X

Gilbert, A. (2012b). Rental Markets and Rental Policies in Less Developed Countries. In S. Smith et al. (Eds.), The International Encyclopedia of Housing and Home (pp. 381-386). Amsterdam: Elsevier. https://doi.org/10.1016/B978-0-08-047163-1.00463-X

Gilbert, A. (2016). Rental Housing: The International Experience. Habitat International, 54, 173-181. https://doi.org/10.1016/j.habitatint.2015.11.025

Glasser, D. (1988). The Growing Housing Crisis in Ecuador. In C. V. Patton (Ed.), Spontaneous Shelter: International Perspectives and Prospects (pp. 78-102). Philadelphia, PA: Temple University Press.

Gough, K. V. (2018). Doing Longitudinal Urban Research. In J. Harrison, \& M. Hoyler (Eds.), Doing Global Urban Research (pp. 196-210). London: Sage.

Grajeda, E. (2015). On Housing, Inheritance and Succession among Pioneer Squatters and Self Builders: A Mexican Case Study. In C. Klaufus, \& A. Ouweneel (Eds.), Housing and Belonging in Latin America (pp. 104-122). New York: Berghahn. https://doi.org/10.2307/j.ctt9qdb7t.9

Grajeda, E., \& Ward, P. (2012). Inheritance and Succession among Second and Third Generation Squatter Households in Mexico City. Latin American Research Review, 47, 139-162. https://doi.org/10.1353/lar.2012.0057

Hanson, G. T. (1975). Shantytown Stage Development: The Case of Kingston, Jamaica. Doctoral Dissertation, ProQuest Dissertations and Theses Global.

Hoffman, A. V. (2000). A Study in Contradictions: The Origins and Legacy of the Housing Act of 1949. Housing Policy Debate, 11, 299-326.

https://doi.org/10.1080/10511482.2000.9521370

Housing Europe (n.d.). https://www.housingeurope.eu

Howard, D. (2019). New Agendas and "Good” Urbanism? Shelter and Tenure Transition in a Low-Income Jamaican Neighborhood. International Development Planning Review, 41, 435-450. https://doi.org/10.3828/idpr.2019.23

Jiménez, E. R. (2014). The Whys and Wherefores of Renting in Consolidated Colonias of Guadalajara. In Research Workshop "Housing Market Function and Dysfunction in Consolidated Self-Help Neighborhoods: Towards "Smart" Densification". Presentation at a Policy Workshop on "Smart Densification", March 19, 2014, at the L.B.J. School of Public Affairs, The University of Texas at Austin, TX, USA.

Jiménez, E. R., \& Camargo Sierra, A. C. (2015). Rental Markets and Housing Policies in Consolidated Informal Settlements. In P. M. Ward, \& J. Di Virgilio (Eds.), Housing Policy in Latin American Cities (pp. 283-305). Abingdon-on-Thame: Routledge.

Jiménez, E. R., Cruz-Solis, H., \& Ubaldo-Velzáquez, C. (2019). Preventing "Clouded" Titles in Previously Informal Settlements. The Administrative and Judicial Transmission of Property. Bulletin of Latin American Research, 38, 138-157. In: Salazar, C., Ed., Informality Revisited: Latin American Perspectives on Housing, the State and the Market, 139-158. https://doi.org/10.1111/blar.12985

Kowarick, L. (1994). Social Struggles and the City: The Case of Sao Paulo (Chapter 2: One Hundred Years of Overcrowding). New York: Monthly Review Press. 
Lewis, O. (1966). The Children of Sanchez: Autobiography of a Mexican Family.

López, A., Fraça, E., Prado Costa, K., \& Knoll, F. (2010). Cortiços: A Experiencia de São Paulo. Habitação: S.P. Prefeitura de SP.

Mayne, A. (2017). Slums: The History of a Global Injustice. London: Reaktion Books.

Reyes, A., Reyes, A., \& Daigle, C. (2020). Looking Back to Look Forward: Evolution of the Habitat Agenda and Prospects for Implementation of the New Urban Agenda. Current Urban Studies, 8, 337-363. https://doi.org/10.4236/cus.2020.82019

Rojas, D., Ward, P. M., Peek, O., \& Lazarte, M. (2015). Rehab, “Los Aires” and Densification of Consolidated Settlements in Lima Peru. In P. M. Ward, E. R. J. Jiménez, \& M. M. Di Virgilio (Eds.), Housing Policy in Latin American Cities: A New Generation of Strategies and Approaches for 2016 UN-Habitat III (pp. 160-191). Abingdon-on-Thames: Routledge.

Scobie, J. (1974). Buenos Aires: From Plaza to Suburb 1870-1910. New York: Oxford University Press.

Scheba, A., \& Turok, I. (2020). Informal Rental Housing in the South: Dynamic But Neglected. Environment \& Urbanization, 32, 109-132. https://doi.org/10.1177/0956247819895958

Stiphany, K. (2019). Rentscapes: Emerging Patterns of Informality in São Paulo, Brazil. Presentation at American Collegiate Schools of Planning (ACSP) Annual Conference. Greenville South Carolina, USA. 19 November, 2019.

Stiphany, K., Ward, P. M., \& Palazzi, L. (2020). Situated Data: “Slum” Upgrading and Rise of Informal Rental in São Paulo, Brazil.

Tindigarukayo, J. (2002). The Squatter Problem in Jamaica. Social and Economic Studies, 51, 95-125.

Tindigarukayo, J. K. (2014). The Impact of Rural-Urban Influx on Jamaican Society. International Journal of Humanities and Social Science, 4, 35-40.

Turner, J. F. C. (1968). Housing Priorities, Settlement Patterns and Urban Development in Modernizing Countries. Journal, American Institute of Planners, 34, 354-363. https://doi.org/10.1080/01944366808977562

Varley, A. (1993). Gender and Housing: The Provision of Accommodation for Young Adults in Three Mexican Cities. Habitat International, 17, 13-30. https://doi.org/10.1016/0197-3975(93)90026-9

Ward, P. M. (1998). Mexico City. Hoboken, NJ: Wiley.

Ward, P. M. (2012). A Patrimony for the Children: Low-Income Homeownership and Housing (Im)Mobility in Latin American Cities. Annals of the Association of American Geographers, 102, 1489-1510. https://doi.org/10.1080/00045608.2011.628260

Ward, P. M., \& Jiménez, E. (2011). Self-Help Housing Policies for Second Generation Inheritance and Succession of the House that Mum and Dad Built. (In Collaboration with Erika Grajeda and Claudia Ubaldo Velázquez). Habitat International, 35, 467-485. https://doi.org/10.1016/j.habitatint.2010.12.005

Ward, P. M., Jiménez, E. R., \& Virgilio, M. M. (2015). Housing Policy in Latin American Cities: A New Generation of Strategies and Approaches for 2016 UN-HABITAT III. Abingdon-on-Thames: Routledge. https://doi.org/10.4324/9781315773001

Wyke, T., Robson, B., \& Dodge, M. (2018). Manchester: Mapping the City. Manchester, UK: Birlinn General. 